\title{
Implementasi Penatausahaan, Pengelolaan, dan Pelaporan Alokasi Dana Desa Dalam Proses Pembangunan Desa Bimorejo Kecamatan Wongsorejo Kabupaten Banyuwangi Tahun 2015
}

\author{
(Implementation Of The Administration, Management, And Reporting The \\ Village Fund Allocation In The Development Process Bimorejo Village Sub- \\ District Wongsorejo District Banyuwangi In 2015)
}

\author{
Maulita Sofie R, Rohman Effendi' ${ }^{1}$, Djoko Supatmoko \\ Jurusan Akuntasi, Fakultas Ekonomi, Universitas Jember (UNEJ) \\ Jln. Kalimantan 37, Jember 68121 \\ E-mail:maulitasofie@yahoo.co.id
}

\begin{abstract}
Abstrak
Penelitin ini fokus terhadap penerapan penatausahaan, pengelolaan dan pelaporan alokasi dana desa (ADD) di Desa Bimorejo pada Tahun 2015. Penatausahaan sebagai bentuk pertanggungjawaban, penyajian, pelaporan dan mengungkapkan segala aktivitas dan kegiatan yang menjadi tanggung jawab pemerintah desa kepada publik. Penelitian ini dilakukan untuk mengetahui makna penatausahaan, pengelolaan, dan pelaporan alokasi dana desa (ADD) di Desa Bimorejo. Penelitian ini didukung dengan adanya pengawasan teknis, operasional dan evaluasi yang dilakukan Tim Pendamping Kecamatan, Badan Pemberdayaan Desa guna membuktikan adanya penerapan akuntabilitas dan transparan dalam pengelolaan alokasi dana desa di Desa Bimorejo. Pengumpulan data dilakukan dengan metode observasi terbuka dan wawancara. Sebagai informan penelitian ini ada 4 responden yaitu BPM-PEMDES, Kepala Desa, Sekretaris Desa, Bendahara Desa. Penelitian ini adalah penelitian analisis deskriptif dengan pendekatan kualitatif. Hasil penelitian ini menunjukkan bahwa penerapan penatausahaan, pengelolaan dan pelaporan alokasi dana desa (ADD) sudah menerapkan prinsip akuntabel dengan indikator partisipatif, transparan dan responsif sesuai dengan pedoman yang berlaku.
\end{abstract}

\begin{abstract}
This study focuses on the application of accountability system, which is a form of responsibility over the management of public funds by the Government which was done starting from the planning stages, execution, implementation, and surveillance of the management of village Funds Allocation. This study was conducted because of the amount of the funds allocated for rural development as well as susceptible to fraud resulting from the lack of transparency of reporting to the public, as well as the performance of the implementation Team in the village of accountable reporting accountability that has not been in accordance with the applicable regulations. This study is expected to be beneficial to the Government of Banyuwangi Regency especially Rogojampi Sub-district in an attempt to improve the accountability of the management of the village Funds Allocation. This study was conducted in nine villages in Rogojampi sub-district. The Data collected by direct observation in the villages and with interviews with the parts of County, district monitoring teams, Treasurer of villages, village of Consultative Body Elements, as well as representatives of the villagers. This study shows that in the planning and the execution were in accordance with the applicable pr,ocedures and operations have been conducted in a transparent and accountable. For the surveillance phase is still not going well because of lack of transparency towards the public. As for the implementation phase also has not run properly due to human resources managing team in making the Administration report is still lacking, so the necessary existence of coaching and supervision over local government.
\end{abstract}

\section{Pendahuluan}

Berdasarkan dengan penyelenggaraan pemerintah daerah, yang mengatur dan mengurus sendiri urusan pemerintah menurut asas otonomi dan tugas pembantuan, diarahkan untuk dapat mempercepat terwujudnya kesejahteraan masyarakat melalui peningkatan pelayanan, pemberdayaan, dan peran masyarakat, serta peningkatan daya saing daerah dengan memperhatikan sebuah prinsip demokrasi, pemerataan, keadilan, keistimewaan dan kekhususan suatu daerah dalam sistem Negara Kesatuan Republik Indonesia. Pemerintah juga harus dapat menunjang pelaksanaan tata kelola yang baik dalam melaksanakan pemerintahan desa dengan melakukan transparansi, akuntabilitas, efektifitas, dan efisien terhadap pengelolaan Alokasi Dana Desa (Suparmoko, 2010).
Menurut Nordiawan (2012:7-8), Tujuan pokok dari akuntansi pemerintahan dalam pengelolaan keuangan publik adalah dalam pertangungjawaban, manajerial, dan pengawasan. Pertanggungjawaban yang dilakukan pemerintah adalah dengan memberi informasi keuangan yang lengkap, cermat, dan dalam bentuk dan waktu yang tepat selama periode yang ditentukan. Akuntansi pemerintahan juga harus menyediakan informasi dalam proses manajerial seperti perencanaan, penganggaran, pelaksanaan, pengawasan, pengendalian anggaran, perumusan kebijakan, pengambilan keputusan, dan penilaian kinerja pemerintah atas keuangan publik. Selain itu juga diperlukan adanya pengawasan secara terarah, ekonomis, efisien, efektif, berkeadilan, dan terkendali atas penggunaan keuangan publik. Mewujudkan pemerintahan yang baik, perlu adanya peningkatan dalam sebuah prinsip

1 Penulis Korespondensi 
demokrasi, yaitu pemerintahan dari rakyat, oleh rakyat, dan untuk rakyat.

Dalam sebuah proses demokrasi, peran ilmu akuntansi pemerintah khususnya dalam prinsip akuntabilitas publik menjadi salah satu hal yang sangat krusial karena menjadi prasyarat dasar dari keberhasilan demokrasi itu sendiri. Akuntansi Pemerintahan memiliki peran dalam pengelolaan keuangan publik dalam mewujudkan tata kelola pemerintahan yang baik, mulai dari tata kelola keuangan pusat, daerah, maupun desa. Prinsip dalam akuntansi pemerintahan seperti akuntabilitas dan transparansi pengelolaan Keuangan publik bukan hanya sebagai bentuk kewajiban dari pemerintah pusat, namun juga daerah seperti desa (Sherly, 2014).

Desa memiliki peran yang penting, khususnya dalam pelaksanaan tugas di bidang pelayanan publik. Desentralisasi kewenangan-kewenangan yang lebih besar disertai dengan pembiayaan dan bantuan sarana prasarana yang memadai mutlak diperlukan guna penguatan otonomi desa menuju kemandirian desa. Dengan diterbitkannya Undang-Undang No 6 tahun 2014 tentang desa, posisi pemerintahan desa menjadi semakin kuat. Kehadiran undang-undang tentang Desa tersebut disamping merupakan penguatan status desa sebagai pemerintahan masyarakat, sekaligus juga sebagai basis untuk memajukan masyarakat dan pemberdayaan masyarakat desa (Marwan, 2015)

Pemerintah harus dapat mengeluarkan sebuah kebijakan dalam pembentukan Alokasi Dana Desa (ADD) yang cukup signifikan bagi desa untuk menunjang program-program desa. Pengelolaan keuangan baik dari anggaran sampai realisasi harus dapat melibatkan tokoh-tokoh masyarakat dan aparat Pemerintah Daerah. Kendala-kendala yang dihadapi oleh Pemerintah Daerah baik Pemerintah Desa, Pemerintah Kecamatan adalah kurangnya pengendalian terhadap pengelolaan Dana yang berasal dari Alokasi Dana Desa, hal ini disebabkan karena minimnya sumber daya yang ada dan kontrol dari Pemerintah dan Masyarakat. Untuk itu perlu diketahui sejauh mana implementasi penatausahaan, pengelolaan, dan pelaporan Alokasi Dana Desa dalam Pembangunan Desa. Sesuai dengan Permendagri No. 113 Tahun 2014 Tentang pengelolaan keuangan desa adalah keseluruhan kegiatan yang meliputi perencanaan, pelaksanaan, penatausahaan, pelaporan dan pertanggungjawaban keuangan desa (Wida, 2015).

Kabupaten Banyuwangi merupakan salah satu daerah otonom yang ada di Jawa Timur yang melaksanakan prinsip-prinsip otonomi daerah dengan berusaha mengoptimalkan potensi desa demi terselenggaranya pemerintahan yang bersih dan transparan. Pedoman alokasi dana desa tertera dalam Perbup No. 13 Tahun 2015 dan Perda No. 2 Tahun 2007 menjelaskan mengenai petunjuk pelaksanaan dan pedoman teknis Alokasi Dana Desa yang selanjutnya disingkat ADD adalah dana yang dialokasikan oleh pemerintah kabupaten untuk Desa, yang bersumber dari Bagian Dana Perimbangan. Keuangan Pusat dan Daerah kecuali Dana Alokasi Khusus. Bagi hasil dari Pajak Daerah dan Bagi Hasil dari Retribusi tertentu yang diterima Kabupaten.

Alokasi Dana Desa dilaksanakan dengan prinsip keterbukaan/transparansi sebagai wujud pertanggungjawaban kepada publik. Alokasi Dana Desa merupakan hal yang tidak terpisahkan oleh pengelola keuanagan Negara. Pengelolaan alokasi dana desa dibagi menjadi pos pembiayaan besar, yaitu $20 \%$ dialokasikan untuk membiayai kegiatan operasional penyelenggaraan pemerintah desa dan $80 \%$ dialokasikan untuk membiayai pemberdayaan masyarakat. Berdasarkan Peraturan Bupati Nomor 13 tahun 2015, kebijakan yang diambil oleh Pemerintah Kabupaten Banyuwangi dalam mendistribusikan dana ADD dengan asas merata dan adil. Penelitian ini dilaksanakan di Jalan Raden Bronto No. 21 Desa Bimorejo Kecamatan Wongsorejo Kabupaten Banyuwangi. Kecamatan Wongsorejo yang merupakan wilayah Kabupaten Banyuwangi yang berada paling utara, memiliki luas $464.80 \mathrm{Km}^{2}$ dengan jumlah penduduk total 74.698 jiwa yang terdiri dari 12 desa dan 31 dusun (Sumber : Kecamatan Wongsorejo, 2012). Pembagian Alokasi Dana Desa di wilayah kecamatan Wongsorejo dapat dilihat di tabel 1 berikut ini :

Tabel 1. Alokasi Dana Desa di Kecamatan Wongsorejo

\begin{tabular}{clr}
\hline NO & \multicolumn{1}{c}{ DESA } & $\begin{array}{c}\text { ADD Tiap Desa } \\
(\mathrm{Rp})\end{array}$ \\
\hline 1 & Bangsring & $355.233 .000,00$ \\
\hline 2 & Bengkak & $336.664 .000,00$ \\
\hline 3 & Alasbulu & $380.164 .000,00$ \\
\hline 4 & Wongsorejo & $352.857 .000,00$ \\
\hline 5 & Alasrejo & $326.255 .000,00$ \\
\hline 6 & Sumberkencono & $330.028 .000,00$ \\
\hline 7 & Sidowangi & $332.255 .000,00$ \\
\hline 8 & Sidodadi & $339.339 .000,00$ \\
\hline 9 & Bajulmati & $313.139 .000,00$ \\
\hline 10 & Watukebo & $375.059 .000,00$ \\
\hline 11 & Sumberanyar & $322.527 .000,00$ \\
\hline 12 & Bimorejo & $319.615 .000,00$ \\
\hline & JUMLAH & $4.083 .015 .000,00$ \\
\hline
\end{tabular}

Sumber : BPM-Pemdes 2015 (data diolah, Mei 2015)

Kecamatan Wongsorejo memiliki 12 Desa. Desa Bimorejo merupakan merupakan salah satu desa yang menerima Alokasi Dana Desa terkecil kedua setelah desa yang lainnya. Meskipun Desa Bimorejo menerima Alokasi Dana Desa yang cukup kecil tidak besar kemungkinan pihak pemerintah desa mengabaikan sistem pengelolaan Alokasi Dana Desa yang cukup signifikan. Oleh karena itu pengelolaan Alokasi Dana Desa merupakan salah satu visi dan misi Kabupaten Banyuwangi yang mementingkan kesejahteraan masyarakat desa melalui optimalisasi penggunaan Alokasi Dana Desa yang sesuai dengan arah kebijakan nasional dan Rencana Pembangunan Jangka Menengah Daerah (RPJMD) Kabupaten Banyuwangi.

\section{Metode}

Penelitian ini adalah penelitian analisis deskriptif dengan pendekatan kualitatif. Pendekatan kualitatif merupakan metode-metode yang mengeksplorasi dan memahami makna yang dari sekelompok orang atau individu yang berasal dari masalah sosial. Proses penelitian kualitatif melibatkan upaya-upaya dalam prosedur-prosedur pengumpulan data yang spesifik dari para partisipan.

Desain penelitian deskriptif adalah desain penelitian yang disusun dalam rangka memberikan gambaran secara 
sistematis dan induktif tentang informasi ilmiah yang berasal dari subjek atau objek penelitian. Sumber data dalam penelitian ini dilakukan dengan duacara yaitu: Data primer adalah data yang diperoleh langsung darisumbernya dengan cara Observasi dan interview/wawancara terstruktur dan Data sekunder adalah data yang diperoleh dari pihak ketiga atau literature, dokumentasi, tulisan-tulisan sebagai pembanding dari data yang diperoleh yaitu bukubuku referensi, Undangundang, dan Media elektronik. Teknik pengumpulan data yang digunakan dalam penelitian ini adalah sebagai berikut (Creswell, 2007) : Wawancara peneliti dapat melakukan face-to-face interview (wawancara berhadap-hadapan) dengan partisipan, wawancarai mereka dalam focus-group interview (interview dalam sekelompok tertentu ) yang terdiri dari beberapa partisipan kelompok. Wawancara seperti ini tentu saja melakukan pertanyaan-pertanyaan yang secara umum tidak terstruktur dan bersifat terbuka yang dirancang untuk memunculkan pandangan dan opini dari para partisipan dan Dokumentasi adalah teknik pengumpulan data sekunder dengan berbagai sumber yang ada diluar seperti dokumen publik dan dokumen privat.

Dokumentasi diperlukan dalam pengelolaan ADD Peraturan Menteri Dalam Negeri No. 113 Tahun 2014 tentang Pengelolaan Keuangan Desa, UU No 6 Tahun 2014 Tentang Dana Desa, Perdes No 1 Tahun 2013 mengenai anggaran pendapatan dan belanja desa dan pedoman-pedoman lain yang bersangkutan terhadap pengelolaan ADD di Kabupaten Banyuwangi. Menurut Yin (2006) Desain penelitian yang dikategorikan sebagai studi kasus, ditentukan oleh unit analisisnya. Dalam penyusunan penelitian ini, unit analisis yang digunakan peneliti adalah Kantor Desa Bimorejo Kecamatan Wongsorejo Kabupaten Banyuwangi sebagai penerapan implementasi penatausahaan, pengelolaan, dan pelaporan Alokasi Dana Desa yang sesuai dengan Permendagri No. 113 Tahun 2014 dan Perbup No. 13 Tahun 2015. Fokus Penelitian merupakan penjelas dari kerangka pemikiran. Dalam penelitian ini yang menjadi fokus penelitian adalah penerapan penatausahaan, pengelolaan, dan pelaporan Alokasi Dana Desa Bimorejo sesuai dengan Permendagri No. 113 Tahun 2014 dan Perbup No. 13 Tahun 2015. Adapun prinsip-prinsip tersebut yaitu : Akuntabilitas Upaya pemerintah bertanggungjawab atas aktivitas yang telah dilakukan untuk menciptakan upaya penilaian masyarakat. Transparansi Merupakan prinsip penting untuk pelaporan aktivitas kegiatan pengelolaan Alokasi Dana Desa untuk menghindari kesalahpahaman informasi dan pertanggungjawaban berbagai pihak. Keabsahan data dilakukan dengan tujuan menguji kepercayaan terhadap data hasil dari penelitian. Untuk menguji keabsahan data yang diperoleh, dalam penelitian ini menggunakan dua metode, yaitu : Triangulasi Menurut Sugiyono (2010 : 125) metode triangulasi adalah metode yang mengecek keabsahan data dengan memanfaatkan sesuatu yang lain. Hal itu dapat dilakukan dengan cara membandingkan data hasil pengamatan dan juga hasil wawancara dari informan satu dengan informan yang lainnya, membandingkan pendapat satu orang dengan orang yang lainnya, serta dengan penyelarasan antara data yang diperoleh dengan kondisi yang sesungguhnya ada dan Member Check adalah proses pengecekan data yang dilakukan oleh peneliti kepada subjek penelitian atau narasumber.
Hal ini bertujuan untuk mengetahui seberapa jauh data yang diperoleh sesuai dengan yang disampaikan oleh narasumber. Selain itu, tujuan member check adalah agar responden dapat memberikan informasi baru lagi atau responden dan pembimbing dapat menyetujui kebenarannya sehingga hasil penelitian dapat lebih dipercaya (Usman, 2009 : 81).

\section{Hasil dan Pembahasan}

Penelitian ini dilakukan di Desa Bimorejo Kecamatan Wongsorejo Kabupaten Banyuwangi yang memiliki luas wilayah $464.80 \mathrm{Km}^{2}$ dan jumlah penduduk sebesar 4.841 Jiwa. Implementasi penatausahaan merupakan salah satu perwujudan pengelolaan Alokasi Dana Desa yang mana dalam pengelolaan ADD selalu ada beberapa prosedur yang harus dikelola oleh pemerintah desa sebagaimana penatausahaan keuangan desa yang terdiri dari beberapa bagian, yaitu penatausahaan penerimaan yang meliputi pendapatan desa semua penerimaan uang melalui rekening desa yang merupakan hak desa dalam 1 (satu) tahun anggaran yang tidak perlu dibayar kembali oleh desa, yaitu Alokasi Dana Desa (ADD) dari APBD merupakan sebuah dana yang diperoleh dari pemerintah kabupaten yang dialokasikan khusus untuk desa dalam proses pembangunan desa. Perhitungan dari Dana perimbangan yang diterima oleh Kabupaten sebesar 10\% setelah dikurangi dengan Dana Alokasi Khusus (DAK). Dasar hukum pengalokasian Dana Perimbangan ke Desa sesuai dengan amanat dari UndangUndang No. 6 Tahun 2014 Pasal 72 ayat 4. Pemerintah dapat melakukan penundaan atau pemotongan sebesar alokasi Dana Perimbangan setelah dikurangi Dana Alokasi Khusus. Dengan formulasi yang jelas, Alokasi Dana Desa Minimal sebesar $60 \%$ adalah alokasi dana desa yang dibagi secara merata dengan formulasi Dana Perimbangan dikurangi Dana Alokasi Khusus kemudian dikalikan 10\%, dari hasil 10\% dikalikan 60\% dan dibagi jumlah Desa yang ada dikabupaten Banyuwangi.

Sedangkan untuk Alokasi Dana Desa Proporsional adalah 40\% dari Dana Perimbangan dikurangi Dana Alokasi Khusus atau sisa Alokasi Dana Minimal.Pembagian Alokasi Dana Desa sudah ditetapkan berdasarkan Keputusan Bupati Banyuwangi No. 188/273/KEP/429.011/2015 dimana Desa Bimorejo, Kecamatan Wongsorejo memperoleh Alokasi Dana Desa sebesar Rp 319.615.000. Penatausahaan Pengeluaran merupakan bagian dari prosedur pengeluaran desa yang berupa belanja desa yang mana meliputi seluruh pengeluaran dari rekening desa yang merupakan kewajiban desa dalam 1 (satu) tahun anggaran yang tidak akan diperoleh pembayarannya kembali oleh desa. Dalam belanja desa kegiatan yang bersifat tunai yang dikeluarkan oleh Bendahara Desa dibuatkan bukti kwitansi pengeluaran dan dicatat oleh Bendahara Desa pada Buku Kas Umum. Sedangkan untuk Belanja yang bersifat transfer langsung ke pihak ketiga, Bendahara Desa melakukan pencatatan ke dalam Buku Bank (tidak dicatat di BKU, karena BKU untuk transaksi tunai).

Pencatatan penerimaan baik kas maupun transfer harus disertai dengan bukti yang lengkap dan sah serta dicatat secara benar dan tertib. Selain pencatatan transaksi pada Buku Kas umum atau Buku Bank, Bendahara juga mencatat kewajiban perpajakan yang dipotong/dipungut atas transaksi belanja yang dilakukan atas pemotongan/pemungutan dalam Buku Pajak ketika bendahara desa melakukan penyetoran ke 
Kas Negara dengan batasan waktu yang diatur dalam ketentuan perpajakan melalui form Surat Setoran Pajak (SPP) maka bendahara Desa mencatat dalam buku Pembantu Pajak pada kolom pengeluaran. Penatausahaan oleh Pelaksana Kegiatan merupakan sebuah awal dalam pelaksanaan dimana pelaksanan kegiatan yang melakukan pengajuan kegiatan berserta besaran pendanaan kegiatan yang sudah dituangkan dalam Rencana Anggaran Biaya (RAB) setelah itu dilakukan pencatatan dalam Buku Pembantu Kas yang diverifikasi oleh Sekertaris Desa. Pelaksana kegiatan berdasarkan fungsi tersebut pelaksana kegiatan (PK) mengajukan pendanaan untuk melakukan kegiatan dalam program pengelolaan Alokasi Dana Desa yang disusun dalam Rencana Anggaran Biaya (RAB) yang harus disetujui oleh Sekretaris Desa dan Pelaksana Kegiatan juga membuat dokumen Buku Pembantu Kas untu proses tindakan pengeluaran yang menyebabkan beban anggaran belanja kegiatan yang ada dalam Rencana Anggaran Biaya setelah itu melakukan pengajuan pendanaan untuk pelaksanaan kegiatan yang menghasilkan beberapa dokumen Surat Permintaan Pembayaran, Pernyataan Tanggungjawab Belanja, dan bukti transaksi untuk diserahkan oleh Kepala Desa agar dilakukan verifikasi pembayaran yang diserahkan ke Bendahara Desa.

Pengelolaan Alokasi Dana Desa dilaksanakan berdasarkan Anggaran Pendapatan dan Belanja Desa (APBDes) didalam pengelolaan Alokasi Dana Desa penyusunan dilakukan oleh Sekretaris Desa berdasarkan Renjana Kerja Pembangunan Desa (RKPDes) disetiap tahunnya, sehingga sekretaris desa menyampaikan Rancangan Peraturan Desa tentang APBDes kepada Kepala Desa. Dalam penyusunan Rancangan APBDes dalam pengelolaan Alokasi Dana Desa sebelumnya Pemerintah Desa Bimorejo melakukan Musyawarah Perencanaan Pembangunan Desa (musrembangdes) yang akan membahas perencanaan-perencanaan kegiatan dari berbagai sektor dan bidang yang yang telah ditentukan oleh Perangkat Desa Bimorejo.

Kegiatan masyarakat tersebut dapat mendukung tugas pemerintah dalam mengetahui kebutuhan masyarakatnya, menyusun agenda dan prioritas pelayanannya, serta dapat melaksanakan agenda yang telah ditetapkan sesuai dengan kebutuhan masyarakat dan sesuai dengan lokal masingmasing desa untuk menumbuhkan potensi desa. Semakin tinggi partisipasi masyarakat, maka semakin mudah pula bagi masyarakat dalam merumuskan dan mewujudkan aspirasi masyarakat. Namun selain peran masyarakat, dipperlukan pula adanya peran dari aparat desa. Peran aparat desa adalah untuk memberikan motivasi pada masyarakat untuk berpartisipasi aktif dalam pembangunan desa.

pengelolaan Alokasi Dana Desa jika sesuai dengan Perbup, maka akan meminimalisir kegiatan kegiatan yang memungkinkan tidak dilaksanakan sesuai Anggaran Pendapatan dan Belanja Desa di Desa Bimorejo. Dalam pengelolaan atau perencanaan Alokasi Dana Desa selalu ada perubahan atau tambahan kegiatan Alokasi Dana Desa sesuai dengan nilai perubahan jenis setiap tahunnya, sehingga pemerintah desa wajib melakukan perubahan atas Rencana Penggunaan Dana Alokasi Dana Desa atau sering disebut (RPD-P) sebagai laporan Rincian Pengunaan Alokasi Dana Desa Bimorejo. Besaran nilai rencana penggunaan dana ADD sebelum perubahan adalah sebesar Rp 319.615.000,00 namun setelah adanya kegiatan Alokasi Dana Desa Bimorejo besarnya nilai ADD memiliki perubahan sebesar Rp 357.597.000,00 sehingga dalam hal ini ADD Desa Bimorejo menambah anggaran sebesar Rp 37.976.000,00Berikut Tabel Rencana Penggunaa Dana Alokasi Dana Desa (RPD-P) Tahun 2015:

Tabel 2. Perubahan Rencana Penggunaan Dana Alokasi Dana Desa Bimorejo (RPD-P) Tahun 2015

\begin{tabular}{|c|c|c|}
\hline No & Uraian & Jumlah Anggaran \\
\hline 1 & $\begin{array}{l}\text { Operasional } \\
\text { Pemerintah Desa }\end{array}$ & $\operatorname{Rp} 232.004 .000,00$ \\
\hline \multirow[t]{3}{*}{2.} & $\begin{array}{l}\text { 1) Penyelenggara } \\
\text { Pemerintah Desa }\end{array}$ & $\operatorname{Rp} 23.252 .000,00$ \\
\hline & Bidang Pemberdayaan & \\
\hline & $\begin{array}{l}\text { Pelaksanaan } \\
\text { Pembangunan Desa }\end{array}$ & \\
\hline \multirow[t]{6}{*}{3.} & $\begin{array}{l}\text { 1) Papingisasi Jalan } \\
\text { Lingk. Mangaran RT } \\
\text { 03/02 Dusun Aseman }\end{array}$ & $\operatorname{Rp} 25.285 .000,00$ \\
\hline & $\begin{array}{l}\text { 2) Pembangunan } \\
\text { Plengsengan/ Talud } \\
\text { penahan Badan Jalan } \\
\text { H. Toyib Dusun } \\
\text { Aseman }\end{array}$ & Rp 16.000.000,00 \\
\hline & $\begin{array}{l}\text { 3) Bedah Rumah } \\
\text { Sederhana bagi } \\
\text { keluarga miskin } \\
\text { Pembinaan } \\
\text { Kemasyarakatan }\end{array}$ & Rp 51.050.000,00 \\
\hline & $\begin{array}{l}\text { 1) Pembinaan } \\
\text { Lembaga } \\
\text { kemasyarakatan }\end{array}$ & Rp 10.000.000,00 \\
\hline & $\begin{array}{l}\text { 2) Pembinaan } \\
\text { Posyandu }\end{array}$ & \\
\hline & Jumlah & Rp 357.591.000,00 \\
\hline
\end{tabular}

Sumber : (Dokumen Rencana Penggunaan Alokasi Dana Desa (RDP-P) Desa Bimorejo Kecamatan Wongsorejo Kab. Banyuwangi Tahun 2015 (data diolah, 2015)

Pelaksanaan Alokasi Dana Desa dilakukan berdasarkan kewenangan desa sesuai dengan penerimaan dan pengeluaran yang dilaksanakan melalui rekening kas desa. Prinsip pelaksanaan Alokasi Dana Desa semakin diperkuat dengan adanya Peraturan Bupati Banyuwangi No 13 Tahun 2015 mengatur pelaksanaan Alokasi Dana Desa dalam mengalokasikan kedalam kegiatan-kegiatan yang telah disusun dalam proses perencanaan desa atau musrembangdes. Oleh karena itu dalam penyusunan pelaksanaan Alokasi Dana Desa terdapat sebuat tim pengelola atau pejabat teknis pengelolaan keuangan desa (PTPKD) Desa Bimorejo Kecamatan Wongsorejo yang sudah diatur dalam Keputusan Kepala Desa Bimorejo Nomor : 188/ /KEP/429.504.2012/2015, dimana Kepala Desa bertindak sebagai penangungjawab kegiatan-kegiatan Alokasi Dana Desa yang ditetapkan oleh APBD, sedangkan secara administratif dalam pengelolaan Alokasi Dana Desa dibedakan menjadi : a. Alokasi Dana Desa yang digunakan untuk penyelenggaraan Pemerintah Desa dan Pemberdayaan Masyarakat selain kegiatan infrastruktur, pelaksananya adalah Kepala Desa, Bendahara Desa, dan Sekretaris Desa. b. 
Alokasi Dana Desa digunakan untuk biaya Pemberdayaan Masyarakat khususnya infrastruktur atau sarana prasarana desa, pelaksanaanya adalah Lembaga Pemberdayaan Masyarakat Desa (LPMD).

Tahap pencairan Alokasi Dana Desa telah ditetapkan dalam APBD kabupaten Banyuwangi yang kemudian disalurkan oleh Teknis pengelola keuangan desa dari pemerintah desa yang pelaksanaannya sesuai dengan besaran Alokasi Dana Desa yang telah ditetapkan oleh Surat Keputusan Bupati Banyuwangi Nomor : 188/ 273/KEP/429.001/2015 Tentang penetapan lokasi dan besaran Alokasi Dana Desa bagi setiap desa di Kabupaten Banyuwangi yang sudah dihitung berdasarkan nilai bobot desa. Penggunaan Alokasi Dana Desa dituangkan Dalam Anggaran Pendapatan dan Belanja Desa (APBDes) Peraturan Desa Bimorejo Kecamatan Wongsorejo Nomor 3 Tahun 2015. Pencairan dilakukan paling lambat 1 bulan setelah APBD kabupaten ditetapkan. Penyaluran dan Pencairan ADD dilakukan apabila sudah dituangkan didalam APBDes. Tahap pencairan dilaksanakan dalam 2 (dua) tahap sebagai berikut : Tahap I paling banyak sebesar 60\% (enam puluh persen) dari total ADD yang dialokasikan untuk desa pada tahun anggaran berjalan sesuai dengan alur kas rencana penggunaan Alokasi Dana Desa. Tahap II sebesar 40\% (empat puluh persen) direalisasikan apabila Kepala Desa telah menyampaikan laporan realisasi sebesar $80 \%$ (delapan puluh persen) dari anggaran yang telah direalisasikan pada tahun berjalan.

Berdasarkan pendapat responden, dapat ditarik kesimpulan bahwa dalam kenyataan pelaksanaan penggunaan Alokasi Dana Desa terjadi perubahan nilai atau besaran sehingga pencairan/ penyaluran Alokasi Dana Desa dikarenakan ada perubahan setiap nilai setiap tahunnya yang mana berubah menjadi 3 (tiga) tahap dikarenakan adanya tambahan tahap PAK jadi dalam pencairan terdapat Tahap I, Tahap II, dan Tahapn PAK dalam program anggaran kegiatan tambahan yang terjadi di Desa Bimorejo Kecamatan Wongsorejo tahap pencairan pertama dilakukan sebesar $60 \%$, Tahap kedua sebesar $40 \%$, dan Tahap ketiga sesuai dengan (PAK) oleh karena itu besaran nilai sesuai tahapan pencairan Alokasi Dana Desa Bimorejo adalah sesuai tabel berikut :

Tabel 4.4 Tahap Perubahan Pencairan Alokasi Dana Desa Bimorejo Tahun 2015

\begin{tabular}{llr}
\hline Tahap & Besaran & \multicolumn{1}{l}{ Jumlah } \\
\hline Tahap I & $60 \%$ & Rp 191.769.000,00 \\
\hline Tahap II & $40 \%$ & Rp 127.846.000,00 \\
\hline Tahap III & PAK & Rp 37.976.000,00 \\
\hline Jumlah & & Rp 357.591.000,00 \\
\hline
\end{tabular}

Sumber : (Dokumen Rencana Penggunaan Dana Alokasi Dana Desa Bimorejo Kecamatan Wongsorejo Kabupaten Banyuwangi Tahun 2015) (data diolah, 2016).

Bentuk pertanggungjawaban keuangan Alokasi Dana Desa secara meteriil dan formil adalah Kepala Desa dan secara administratif dilaksanakan oleh Bendahara Desa. Pertanggungjawaban Alokasi Dana Desa terintegrasi dengan pertanggungjawaban APBDes, sehingga bentuk pertanggungjawaban adalah pertanggungjawaban APBDes. Tata cara dan mekanisme pertanggungjawaban secara fisik dan administratif penggunaan Alokasi Dana Desa sesuai dengan peraturan perundang-undangan yang berlaku. Dalam pertanggungjawaban Alokasi Dana Desa, kepala desa memiliki peran sebagai ketua tim pelaksana yang bertugas untuk mempertanggungjawabkan pengelolaan Alokasi Dana Desa mulai dari perencanaan, hingga pelaksanaan dan pengawasannya. Kepala Desa bersama dengan bendahara desa dan bagian Badan Permusyawaratan Desa memiliki kewajiban dan bertanggungjawab terhadap pelaksanaan Alokasi Dana Desa. Setiap kegiatan pengelolaan ADD mulai dari perencanaan hingga pelaksanaan dicatat dan dibuktikan secara sistematis dalam bentuk laporan oleh kepala desa bersama dengan bendahara desa. Pelaksanaan pengelolaan Alokasi Dana Desa bentuk pertanggungjawaban Pemerintah Desa Bimorejo harus melaksanakan pelaporan pengelolaan Alokasi Dana Desa Di Desa Bimorejo Kecamatan Wongsorejo agar Alokasi Dana Desa yang dikelola oleh Pemerintah Desa Bimorejo dapat bersifat Akuntabilitas dan Transparan. Berikut merupakan beberapa pelaporan pertanggungjawaban Di Desa Bimorejo yaitu, Laporan akhir penyerapan dan pemanfaatan Alokasi Dana Desa, Laporan semester pertama berdasarkan anggaran kas untuk Alokasi Dana Desa yang disusun oleh Pemerintah Desa, Realisasi Penggunaan Alokasi Dana Desa dan Realisasi Pelaksanaan APBDes, dan Laporan Realisasi Penggunaan APBDes-P berdasarkan Peraturan Desa Bimorejo.

Pengawasan dan evaluasi pemerintah desa Bimorejo sangat terbuka dalam pengawasan pengelolaan Alokasi Dana Desa disamping agar pengelolaan bisa terpantau dengan baik dan masyarakat desa Bimorejo bisa merasakan sarana dan prasaran dalam proses pembangunan desa yang dilakukan oleh Pemerintah Desa Bimorejo. Oleh karena itu dalam pelaksanaan monitoring atau evaluasi pemerintah desa Bimorejo menunjuk adanya penetapan tim pemeriksanaan pekerjaan maupun pengadaan barang ataupun jasa sesuai dengan Surat Keputusan Kepala Desa Bimorejo Nomor 188/ /KEP/429.504.2012/2015 Tentang Penetapan Tim Pemeriksa Pekerjaan/Barang dan Jasa Desa Bimorejo Kecamatan Wongsorejo Kabupaten Banyuwangi Tahun 2015. Agar setiap proses pelaksanaan pengelolaan Alokasi Dana Desa dapat melakukan kegiatan secara efektifitas dan akuntanbilitas. Pengawasan biasanya dilakukan secara berkala oleh tim pendamping kecamatan dan 2 (dua) kali setiap tahunnya dilakukan oleh bagian Badan Pemberdayaan Masyarakat-Pemerintah Desa.

\section{Simpulan dan Keterbatasan}

Penatausahaan dalam pengelolaan keuangan desa di Desa Bimorejo telah sesuai dengan prosedur yang dilakukan oleh Bendahara Desa dan ditetapkan proses pelaksanaan kegiatan hingga pelaporan kegiatan yang sudah dilakukan pencatatan dan prosedur penatausahaan yang telah diatur dalam Permendagri No. 113 Tahun 2014 hingga tercatat secara baik dan terperinci yang dituangkan dalam tiap laporan penyerapan Alokasi Dana Desa dan Laporan Realisasi APBDes yang telah diatur sesuai dengan Peraturan Bupati Kabupaten Banyuwangi No 13 Tahun 2015. Pengelolaan dalam Alokasi Dana Desa yang dituangkan dalam Anggaran Pendapatan dan Belanja Desa (APBDes) peneliti menyimpulkan bahwa terdapat 4 (empat) bagian, yaitu : Penghasilan tetap kepala desa dan Perangkat Desa 30\% untuk penghasilan tetap sudah sesuai dengan Permendagri No. 113 Tahun 2014 dan Perbup No. 13 Tahun 2015, 
Penyelanggaraan Pemerintah Desa sesuai dengan Perbup No. 13 Tahun 2015 paling banyak sebesar 50\% dari ADD-SilTap, Pembangunan sesuai dengan Perbup N0. 13 Tahun 2014 paling sedikit 50\% dari ADD-SilTap digunakan untuk Papingisasi Jalan Lingk Mangaran RT 03/02 Dusun Aseman, Pembangunan Plengsengan Talud Penahan Badan Jalan H. Toyib Dusun Aseman, dan Bedah Rumah Sederhana, Pembinaan dan Pemberdayaan Masyarakat digunakan untuk lembaga kemasyarakatan dan pembinaan posyandu.

Pertanggungjawaban dalam pengelolaan Alokasi Dana Desa di Desa Bimorejo Kecamatan Wongsorejo Kabupaten Banyuwangi telah berlangsung baik dengan melakukan tiap dokumentasi setiap kegiatan dalam bentuk laporan yang telah ditentukan berdasarkan prosedur yang telah ditetapkan. Bentuk pelaporan Pengelolaan Alokasi Dana Desa Bimorejo ada yang bersifat sistem seperti melaporkan di E-Village Budgeting namun ada juga yang secara manual seperti adanya Laporan penyerapan dan penggunaan ADD, Laporan semester pertama, Perdes APBDes penggunaan ADD. Hambatan pengelolaan keuangan desa sesuai dengan Permendagri No. 113 Tahun 2014 adalah adanya keterbatasan anggaran dana desa dan adanya kesenjangan pertanggungjawaban dan responsive antara partisipasi masyarakat dalan anggaran Desa.

\section{Keterbatasan}

Pengawasan untuk Tim Kabupaten hanya dari pelaporan sistem E-Village Budgeting tidak secara langsung. Dalam penelitian ini terdapat juga keterbatasan hasil evaluasi dan monitoring pada saat melakukan pengawasan, pemerintah desa Bimorejo kecamatan wongsorejo tidak melakukan pengarsipan hasil evaluasi kegiatan. Pada penelitian ini, peneliti tidak melakukan semua check list semua bukti pembelian atau kwitansi setiap adanya pengadaan barang atau jasa, peneliti hanya melakukan sampling terhadap 1 (satu kegiatan) yang terdapat dalam buku kas pembantu kegiatan yaitu kwitansi pengadaan barang/jasa pada saat melakukan musyawarah perencanaan dan pembangunan desa (musrembangdes) Desa Bimorejo.

\section{Referensi}

Aprilliana, Sherly Greshita. 2014. "Akuntabilitas Pengelolaan Alokasi Dana Desa Di Desa Kedungrejo Kecamatan Muncar Kabupaten Banyuwangi Tahun 2013”. Tidak Diterbitkan. Skripsi. Jember : Universitas Jember

Arifiyanto, Febri. 2014. "Akuntabilitas Pengelolaan Alokasi Dana Desa Di Kecamatan Umbulsari Kabupaten Jember Tahun 2012". Jurnal Ilmiah. Jember : Universitas Jember

Badan Pemberdayaan Masyrakat Pemerintah Desa Banyuwangi-Alokasi Dana Desa.

http://bpm.banyuwangikab.go.id/ (diakses tanggal 23 Februari 2016) (Pukul 6.56)

Badan Pengelolaan Keuangan Pemerintah., 2015. "Petunjuk Pelaksanaan Bimbingan \& Konsultasi Pengelolaan Keuangan Desa”. Deputi Bidang Pengawasan Penyelenggaraan Keuangan Daerah. Indonesia (AIPI).

Creswell, J.W \& Piano Clark, V.L. (2007). "Designing and Conducting, Mixed Methods Research". Thousand Oaks, CA:Sage.

Huri, Risti Valentina. 2014. "Akuntabilitas Pengelolaan Pemanfaatan Alokasi Dana Desa Dalam Proses Pembangunan Di Desa Dasri Kecamatan Tegalsari Kabupaten Banyuwangi Tahun 2013".Skripsi. Tidak Diterbitkan. Jember : Universitas Jember

Jafar, Marwan. 2015. "Indeks Desa Membangun”. Kementerian Desa, Pembangunan Daerah Tertinggal dan Transmigrasi, Jakarta Selatan.

Kementerian Keuangan, 2015. "Kebijakan Umum Dana Desa (Berdasarkan UU Nomor 6 Tahun 2014 dan PP Nomor 60 Tahun 2014". Disampaikan dalam Sosialisasi UU 6/2014 di Hotel RedTop Jakarta, 28-30 April 2015.

Peraturan Bupati Banyuwangi. Nomor 13 Tahun 2015. "Pedoman Teknis Dan Tata Cara Penetapan Desaran Alokasi Dana Desa Yang Bersumber Dari Anggaran Pendapatan dan Belanja Daerah Kabupaten Banyuwangi”. Salinan. Banyuwangi.

Peraturan Bupati Banyuwangi. Tahun 2015. "Surat Keputusan Nomor. 188/273/KEP/429.011/2015 Tentang Penetapan Lokasi dan Besaran Alokasi Dana Desa Bagi Setiap Desa Di Kabupaten Banyuwangi Tahun Anggaran 2015". Banyuwangi

Peraturan Menteri Dalam Negeri. Nomor 113 Tahun 2014.

Wida, Siti Ainul. 2016. "Akuntabilitas Pengelolaan Alokasi Dana Desa (ADD) Di Desa-Desa Kecamatan Rogojampi Kabupaten Banyuwangi". Skripsi. Tidak Diterbitkan. Jember : Universitas Jember 